\title{
EDUTECH
}

\section{NOMOPHOBIA DALAM PERSPEKTIF MEDIA, BUDAYA DAN TEKNOLOGI}

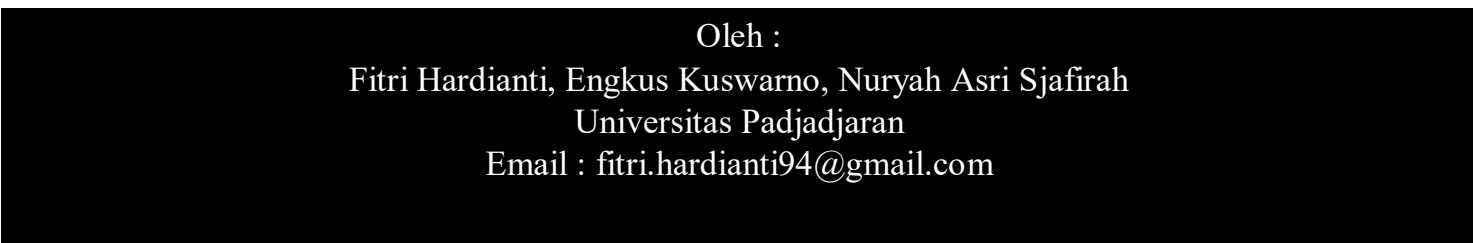

Abstract. Nomopobia is an abbreviation of "No Mobile Phone Phobia" which is a concern that arises when it is far from its Mobile Phone. Those who have a tendency to suffer nomophobia will be overwhelmed by feelings of anxiety when far from the Mobile Phone. The purpose of this study is to find out the meaning of nomophobia in a media, cultural and technological perspective from the point of view of students who have a tendency to nomophobia. The method used in this study is qualitative with a phenomenological approach. The data collection technique used is in-depth interviews. Data analysis techniques used analysis of interactive miles and huberman models. And the technique of data validity uses source triangulation. The results of this study include Nomophobia in a media perspective can be seen from their motives in using a mobile phone. Among these motives is to seek information, as a means to find out the lives of others, and as workrelated needs. Meanwhile, nomophobia in a cultural perspective can be seen from how mobile phone changes the culture of students with the tendency to nomophobia. The ritual of the students where they are daily depends on the presence of a mobile phone, whether it starts from waking up, before leaving for campus or when going to shower, after taking a shower, there are even some informants who keep bringing their mobile phones to the bathroom, in campus until finally when going to sleep also do not miss to check the mobile phone. Meanwhile from the perspective of nomophobia on technology, it can be seen from the meaning of the students regarding the mobile phone itself, among the meanings of the informants regarding Mobile Phone, namely: as a source of information, as a tool that connects with other people, and as a source of income
Informasi Artikel :

Artikel diterima 13 Juni 2019

Perbaikan 16 Maret 2019

Diterbitkan 28 Juni 2019

Terbit Online 30 Juni 2019

Kata kunci: Nomophobia, Media, Culture, Technology and Phenomenology

\section{A. PENDAHULUAN}

Nomofobia secara istilah yakni suatu kecemasan yang luar biasa yang diakibatkan tidak dapat jauh-jauh dari Mobile Phone. Definisi lain dari nomofobia yaitu suatu bentuk kecanduan perilaku terhadap mobile phone dan dimanifestasikan sebagai gejala Psikologis serta ketergantungan fisik (BIVIN.J.B, 2013). Disebut sebagai gejala No. SK Akreditasi Ristekdikti : 34/E/KPT/2018 psikologis, dimana ketika seorang individu bahkan bisa menangis, marah, berteriak dan bisa sampai menyakiti diri sendiri apabila ia tidak dapat mengakses mobile phone nya. Sedangkan ketergantungan fisik, dimana seorang individu bahkan bisa membawa serta mobile phone nya ke kamar mandi, selalu meletakkan mobile phone nya disamping nya ketika tidur dan bahkan bisa sampai DOI:https://doi.org/10.17509/e.v18i2.17134 
ratusan kali dalam sehari membuka screen mobile phone nya walaupun hanya ingin melihat apakah ada notifikasi yang masuk atau tidak. Nomofobia disebut sebagai ketakutan modern apabila tidak dapat berkomunikasi melalui mobile phone atau internet, kata "Nomofobia" pada mulanya berasal dari Inggris, dan digunakan untuk mengekspresikan "No Mobile Phobia" (King, 2014). Nomofobia pada awalnya diteliti oleh seorang mahasiswa dari Iowa State University yang bernama Yildirim, saat itu ia melakukan penelitian kepada 1000 pekerja di perusahaan keamanan di Inggris dan hasil dari penelitian itu menunjukkan bahwasanya terjadi peningkatan dari $53 \%$ ke $66 \%$ yang menderita nomofobia. Hal ini menunjukkan bahwasanya tiap tahun akan terjadi peningkatan masyarakat yang menderita nomofobia, karena wabah ini seperti sesuatu yang tidak bisa dihindari (Yildirim, 2015). Nomofobia kini menjadi suatu fenomena yang melanda dunia, tidak terkecuali di Indonesia. Di Indonesia, fenomena ini baru diketahui pada tahun 2012. Penggunaan mobile phone tentunya sudah menjadi hal yang biasa bagi semua kalangan, baik dari usia remaja hingga orang tua. Adanya teknologi komunikasi mengubah interaksi manusia dengan dunia, persepsi mereka tentang realitas dan interaksi mereka dengan waktu dan ruang. Mobile phone memfasilitasi proses komunikasi individu dan menyediakan tingkat mobilitas yang memungkinkan pengguna mereka dijangkau kapan saja. Selain itu, mobile phone memungkinkan orang untuk ter- hubung dengan orang lain secara nirkabel dan tanpa jaringan lokal fisik. Miniaturisasi teknologi komunikasi memungkinkan fleksibilitas yang luas, mobilitas dan personalisasi (King, 2014). Namun tentunya semuanya harus diimbangi dengan pemakaian yang sewajarnya, tidak dapat dipungkiri penggunaan mobile phone yang berlebihan bisa berakibat pada dampak yang ditimbulkan diantaranya bisa berakibat pada perilaku interpersonal dan juga gejala seperti kegelisahan, ketidaknyamanan dan kecemasan yang disebabkan oleh ketidakmampuan diri seseorang untuk tidak mengakses mobile phone-nya. Bahkan penelitian Kim dari Korea Selatan menyebutkan bahwasanya kecanduan mobile phone bisa berdampak pada kesuksesan atau prestasi siswa (Kim, 2013).

Penelitian lainnya yang menyebutkan dampak dari penggunaan mobile phone yakni penelitian yang dilakukan oleh Fahad D. Alosaimi, dan kawan-kawan. Penelitian ini dimuat di jurnal Saudi Med J pada tahun 2016, yang mana tujuan dari penelitian ini adalah untuk menyelidiki prevalensi dan korelasi kecanduan smartphone di kalangan mahasiswa di Arab Saudi. Penelitian ini menggunakan metode kuantitatif dengan hasil penelitiannya menunjukkan bahwa dari 2367 subjek penelitian, 27,2\% menyatakan bahwa mereka menghabiskan lebih dari 8 jam per hari menggunakan smartphone mereka. Tujuh puluh lima persen menggunakan setidaknya 4 aplikasi per hari, terutama untuk jejaring sosial dan menonton 
berita. Sebagai konsekuensi menggunakan smartphone, setidaknya $43 \%$ mengurangi jam tidur, dan mengalami keletihan pada hari berikutnya, 30\% memiliki gaya hidup yang lebih tidak sehat (makan lebih banyak makanan cepat saji, menambah berat badan, dan berolahraga lebih sedikit), dan $25 \%$ melaporkan bahwa prestasi akademik mereka telah terpengaruh. Ada hubungan positif yang signifikan secara statistik di antara 4 variabel penelitian, konsekuensi penggunaan ponsel cerdas (gaya hidup negatif, prestasi akademik yang buruk), jumlah jam per hari yang dihabiskan menggunakan ponsel cerdas, tahun studi, dan jumlah aplikasi yang digunakan, dan skor variabel hasil pada pompa. Nilai rata-rata dari skala PUMP adalah 60,8 dengan median 60 .

Hasil penelitian berikutnya yakni penelitian yang dilakukan oleh Sonali dkk, dimana tujuan dari penelitian adalah untuk mengetahui tingkat nomofobia pada mahasiswa kedokteran di Universitas KIIT. Dari hasil penelitian diketahui bahwa dari 284 responden, terdapat 7,8\% diantaranya menderita nomofobia berat dan harus dirujuk untuk melakukan konseling. $44 \%$ diantaranya mengeluhkan masalah tidur mereka, dimana perempuan memiliki persentase yang lebih besar terkena nomofobia yakni sebesar $51,1 \%$ dibandingkan laki-laki yang hanya 48,9\% (Kar, 2017).

Penelitian serupa lainnya yang dilakukan oleh Neil Davie, ia menyebutkan bahwasanya semua siswa di universitas South Westphalia memiliki mobile phone dan menggunakannya secara teratur baik di rumah maupun di universitas. Jika dikaji penggunaan reguler yang berlebihan dari apa saja, termasuk perangkat digital, dapat menyebabkan kecanduan yang ada. Menggunakan survei penilaian diri yang dikembangkan di Iowa State University, penelitian ini mengevaluasi apakah nomofobia adalah masalah di institusi tersebut dan sejauh mana nomofobia mempengaruhi para mahasiswa yang ada di institusi tersebut. Sampel non-representatif dari 104 siswa menunjukkan bahwa minoritas kecil $(<3 \%)$ dapat diklasifikasikan sebagai nomofobia berat dan hampir $40 \%$ sebagai nomofobia sedang. Sisanya siswa digolongkan sebagai nomofobia ringan dengan benar-benar nol siswa yang dikategorikan sebagai tidak nomofobia. Ini menciptakan risiko potensial untuk setiap kegiatan yang dipimpin guru, seperti pembelajaran seluler, yang mendorong penggunaan perangkat seluler lebih lanjut. Oleh karena itu disarankan agar situasi ini dipantau dan bahwa masalah nomofobia dimasukkan dalam program masa depan yang mengajarkan literasi digital (Davie, 2017).

Ketersediaan teknologi saat ini nyatanya juga penting dalam pengembangan dan peningkatan produktivitas, tetapi juga membawa beberapa dampak buruk. Demikian juga, teknologi telepon seluler atau mobile phone telah menghubungkan massa dengan cara yang 'ajaib' tetapi penggunaannya yang berlebihan telah membawa banyak implikasi negatif. Nomofobia sendiri sudah berhasil 
mempengaruhi mental dari para pengguna ponsel, yang kemudian oleh persatuan psikolog seluruh dunia nomofobia diusulkan untuk dimasukkan dalam DSM-V (Diagnostik dan statistik manual gangguan Mental, versi kelima) standar manual untuk menilai penyakit kejiwaan. Namun sampai saat ini nomofobia dikategorikan pada jenis addiction.

Mereka yang mengalami kecenderungan Nomofobia tentu saja akan memiliki perilaku -perilaku yang berbeda dibandingkan orangorang pada umumnya yang menggunakan Mobile Phone hanya sebatas sebagai alat komunikasi jarak jauh saja. Seperti yang diungkapkan di dalam penelitian Mahenda (2016) bahwasanya ketika kita ingin melihat seberapa parahnya seseorang yang menderita nomofobia, dapat dilihat dari beberapa indicator, yaiitu lama ia menggunakan mobile phone selama sehari, kuota internet nya, jumlah mobile phone yang ia gunakan dan tidak ketinggalan yakni selalu membawa charger a tau power bank kemanapun ia pergi untuk mengantisipasi jika sewaktu-waktu baterai mobile phone nya melemah (Mahenda, 2013). Mereka yang memiliki kecenderungan nomofobia merasa bahwa menggunakan mobile phone adalah sikap yang tidak bisa ditahan, sebagaimana yang dikatakan Kotler dalam buku irresistible bahwasanya perilaku yang berlebihan merupakan akibat yang dihasilkan dari penggunaan terhadap teknologi dan tugas dari pengguna adalah meminimalisir bahaya dari penggunaan teknologi tersebut (Alter, 2017).
Berdasarkan deskripsi latar belakang yang sudah dijelaskan maka peneliti tertarik untuk meneliti nomofobia dalam sudut pandang ilmu komunikasi, karena pada penelitian terdahulu nomofobia banyak dikaji dan diteliti dalam ilmu terapan, sehingga tantangan bagi peneliti untuk mengkajinya dalam ilmu sosial. Selain itu dengan mengkaji nomofobia dalam berbagai multidisiplin imu diharapkan nantinya didapatkan langkah atau metode yang tepat dalam mengatasi masalah yang berkembang khusunya berkaitan dengan nomofobia.

Pada penelitian ini, penulis mengambil subjek penelitiannya adalah mahasiswa. Adapun alasan peneliti mengambil subjek penelitiannya adalah mahasiswa karena, berdasarkan hasil survey yang dikeluarkan oleh APJII bahwasanya mahasiswa menempati posisi pertama sebagai pengguna mobile phone tertinggi di Indonesia (APJII, 2017).

Adapun tujuan dari penelitian ini adalah untuk mengetahui kaitan antara mahasiswa yang memiliki kecenderungan Nomofobia dalam perspektif fenomenologi dari konsep media, budaya dan teknologi.

Adapun manfaat dari penelitian ini secara teoritis yakni penelitian ini diharapkan dapat memberikan kontribusi atau masukan informasi bagi pengembangan kajian disiplin Ilmu Komunikasi, khususnya berkaitan dengan kajian media. Secara praktis, penelitian ini diharapkan dapat memberikan pemahaman bagi masyarakat pada umumnya untuk lebih bijak dalam menggunakan teknologi khususnya mobile phone dan bagi 
para informan yang memiliki kecenderungan nomofobia agar mengurangi intensitasnya dalam menggunakan mobile phone.

\section{Teori Fenomenologi}

Fenomenologi berasal dari kata yang diambil dari bahasa Yunani yaitu phainomai yang artinya "menampak." Fenomena merupakan suatu fakta yang disadari dan masuk ke dalam penginderaan manusia. Adapun istilah fenomenologi baru diketahui menjelang abad ke-20. Dalam perkembangannya fenomenologi dikenal sebagai aliran filsafat sekaligus metode berpikir, yang mengkaji fenomena manusiawi (human phenomena) tanpa mempertanyakan penyebab dari fenomena tersebut, realitas objektifnya, dan penampakannya. Adapun fenomenologi bertujuan untuk mempelajari bagaimana fenomena dialami dalam kesadaran, pikiran dan dalam tindakan, seperti bagaimana fenomena tersebut bernilai atau diterima secara estetis.

Fenomenologi mencoba mencari pemahaman bagaimana manusia mengkonstruksi makna dan konsep-konsep penting dalam kerangka intersubjektivitas. Intersubjektif karna pemahaman kita mengenai dunia dibentuk oleh hubungan kita dengan orang lain. Walaupun makna yang kita ciptakan dapat ditelusuri dalam tindakan, karya dan aktivitas yang kita lakukan, tetap saja ada peran orang lain didalamnya (Kuswarno, 2009:2).

2. Nomofobia

Nomofobia didefenisikan sebagai "ketakutan yang muncul disebabkan tidak bisa jauh dari mobile phone". Istilah Nomofobia adalah singkatan untuk no- mobile-phone-phobia dan pertama kali diciptakan selama penelitian yang dilakukan pada tahun 2008 oleh Kantor Pos Inggris untuk menyelidiki kecemasan penderita pengguna mobile phone. Untuk merujuk kepada orang-orang dengan Nomofobia, dua istilah lain diperkenalkan dan digunakan bahasa sehari-hari: nomophobe dan nomophobic (Yildirim \& Correia, 2015).

Nomofobia dianggap sebagai gangguan dari dunia modern, dan baru-baru ini digunakan untuk mendeskripsikan tentang ketidaknyamanan atau kecemasan disebabkan tidak tersedianya mobile phone, komputer, atau perangkat komunikasi virtual lainnya secara individual yang menjadi kebiasaan mereka. Walaupun defenisi mereka mencakup ketidaktersediaan komputer, mereka berpendapat bahwa komputer dapat digantikan oleh mobile phone, yang mana diasumsikan kemampuan komputer tersebut dimiliki oleh smartphone dan tablet. Karenanya, mereka mengurangi fokus ke arah komputer tapi lebih membahas lingkungan komunikasi virtual termasuk mobile phone(Yildirim, 2015:6).

\section{Media}

Media menurut kbbi (kbbi, 2018) diartikan sebagai perantara atau penghubung, selain itu juga sebagai sarana dan saluran resmi sebagai alat komunikasi untuk menyebarkan berita dan pesan kepada masyarakat luas. Pernyataan yang mendukung lainnya terkait media bahwasanya dengan adanya berbagai bentuk media komunikasi telah mampu mempermudah manusia dalam 
melakukan interaksi dengan sosial lingkungannya (Sjafirah, 2016 ). Dari pengertian tersebut dapat dipahami bahwasanya media pada awalnya diciptakan untuk memudahkan masyarakat dalam menyampaikan pesan atau mendistribusikan pesan. Media hanyalah sebagai perantara atau alat untuk menghubungkan dua orang atau lebih yang berada pada jarak yang jauh sehingga dengan kehadiran media dapat memudahkan mereka berinteraksi.

Mc Luhan juga menyatakan bahwa media merupakan inti dari peradaban manusia, dominasi media dalam sebuah masyarakat menentukan dasar organisasi sosial manusia dan kehidupan kolektifnya. Mc Luhan kemudian membagi perkembangan manusia dengan mengidentifikasi teknologi media ke dalam empat periode. Pertama, periode tribal. Budaya ucap atau lisan (pra-literit) mendominasi perilaku komunikasi manusia pada saat itu. Ucapan dari mulut ke mulut membuat manusia-manusia yang menggunakannya menjadi sebuah komunitas yang menyeluruh. Selanjutnya kedua, periode literatur. Penemuan alphabet fonetis digunakan oleh manusia sebagai simbol-simbol untuk berkomunikasi secara tertulis tanpa perlu bertatap muka. Dengan adanya budaya baca dan tulisan memudahkan manusia dalam mendapatkan informasi. Ketiga, periode percetakan. Dengan ditemukannya mesin cetak oleh Johan Gutenberg, manusia kemudian memasuki periode percetakan. Buku-buku dan material cetak lainnya dapat digunakan secara massal oleh manusia. Akibatnya, ter- bentuklah homogenitas dalam masyarakat dikarenakan terjadi pengiriman pesan yang sama kepada semua orang. Pada periode ini manusia seperti terisolasi dan masyarakat menjadi tersegmentasi. Terakhir, periode elektronik. Pada periode ini ditemukannya teknologi komunikasi telegraf, dimana selanjutnya terjadi perkembangan teknologi secara terus-menerus sampai saat ini dimana kita mengenal mobile phone (Saefudin, 2008).

\section{Budaya}

Mobile phone diciptakan sebagai alat yang membantu menghubungkan satu orang dengan orang lainnya yang berada pada jarak yang jauh. Mobile phone menarik karena memungkinkan penggunanya untuk menjelajah internet, bekerja dengan orang dari jarak jauh, berbicara dengan teman dan kolega, menyelesaikan masalah dan membuat layanan tanpa meninggalkan lokasi penggunanya saat ini (King, 2014). Jika dikaitkan dengan budaya di Indonesia yakni budaya berkumpulnya atau paguyuban, dimana mobile phone digunakan sebagai media untuk menjalin silaturahmi dengan kerabat yang jauh. Namun saat ini penggunaan mobile phone malah membuat orang yang dekat menjadi jauh, karena fenomena yang terjadi pada saat ini dimana orang-orang yang biasanya saling berinteraksi satu sama lain secara tatap muka lebih memilih untuk memainkan Mobile phone nya dibandingkan berkomunikasi dengan orang disekitarnya, ketergantungan terhadap mobile phone ini membuat perubahan budaya yang ada di In- 
donesia. Pergeseran budaya tadi seolah-olah menjadikan teknologi sebagai pemegang kendali atas manusia, bukan sebaliknya dimana seharusnya manusialah yang memegang kendali atas teknologi. Adapun perubahan mengenai budaya ini akan dibahas lebih lanjut dengan kaitannya pada ritual diri dari mahasiswa dengan kecenderungan nomofobia.

\section{Teknologi}

Teknologi menurut kbbi diartikan sebagai keseluruhan sarana untuk menyediakan barang-barang yang diperlukan bagi kelangsungan dan kenyamanan hidup. Mobile phone merupakan bentuk dari teknologi komunikasi, dimana terus mengalami peningkatan dari tahun ke tahun baik dari segi fitur-fiturnya, koneksi jaringan yang terus mengalami peningkatan dan sebagainya. Dimana pada awalnya mobile phone dikategorikan menjadi kebutuhan tersier, sehingga masih banyak masyarakat yang belum menggunakannya, tetapi kini karena kemajuan dalam teknologi elektronik itu telah menjadi relatif murah dan mudah tersedia untuk individu yang tak terhitung banyaknya. Perangkat yang mudah digunakan saat ini menawarkan kemampuan komputasi canggih dan memegang tempat penting dalam kehidupan sehari-hari (Dongre, 2017 ).

Metode penelitian yang dipilih adalah metode penelitian kualitatif yang pada umumnya bertujuan untuk mendapatkan pemahaman tentang kenyataan melalui proses berpikir induktif. Definisi lain juga disampaikan oleh Bogdan dan Taylor yang menya- takan bahwasanya penelitian kualitatif adalah prosedur penelitian yang menghasilkan data deskriptif berupa kata-kata tertulis atau lisan dari orang-orang dan perilaku yang dapat diamati. Peneliti terlibat dalam situasi dan setting fenomena yang diteliti. Untuk mengungkap dan menjelaskan tentang fenomena nomofobia dalam perspektif media, budaya dan teknologi pada mahasiswa Universitas Padjadjaran yang memiliki kecenderungan Nomofobia dari sudut pandang mereka sendiri, maka penelitian ini menggunakan metode kualitatif dengan tradisi fenomenologi. Makna tentang objek yang diamati dalam penelitian ini dibawa oleh subjek penelitian yaitu mahasiswa Universitas Padjadjaran dengan kecenderungan Nomofobia kepada peneliti. Adapun informan dalam penelitian ini ditentukan dengan teknik purposive sampling. Purposive sampling adalah pemilihan informan berdasarkan pada karakteristik tertentu yang dianggap mempunyai sangkut pautnya dengan karakteristik populasi yang sudah diketahui sebelumnya (Ruslan, 2010). Untuk kriteria dari informan, ketentuannya adalah sebagai berikut. Pertama, para informan merupakan mahasiswa aktif di Universitas Padjadjaran. Kedua, para informan biasanya selalu membawa charger (atau power bank). Ketiga, mereka aktif di media sosial. Keempat, para informan selalu memiliki paket data atau menggunakan wifi agar tetap terhubung dengan internet. Dan kelima, para informan biasanya menggunakan mobile phone minimal 3 jam perhari (Alter, 2017). 
Adapun teknik pengumpulan data yang digunakan adalah wawancara dan observasi. Wawancara menurut Moleong dideskripsikan sebagai percakapan dengan maksud tertentu. Percakapan nantinya dilakukan oleh dua pihak, yaitu pewawancara dalam hal ini peneliti yang mengajukan pertanyaan dan terwawancara dalam hal ini para informan yang memberikan jawaban atas pertanyaan. Pada penelitian ini, nantinya peneliti akan mengajukan sejumlah pertanyaan seputar nomofobia dalam perspektif fenomenologi yang dilihat dari aspek media, budaya dan teknologi kepada kelima informan yang merupakan mahasiswa aktif di Universitas Padjadjaran. Selain dokumentasi juga peneliti nantinya akan melakukan observasi. Observasi diartikan sebagai kemampuan seorang individu dalam hal ini pengamat atau peneliti untuk menggunakan pengamatannya melalui hasil kerja pancaindra mata serta dibantu dengan pancaindra lainnya. Metode observasi adalah metode pengumpulan data yang digunakan untuk mengumpulkan data penelitian melalui pengamatan pancaindra peneliti (Ardianto, 2011). Dalam penelitian ini, peneliti akan melakukan observasi mengenai rutinitas yang dilakukan oleh para informan baik itu di lingkungan kampus dan ketika berada diluar kampus, diharapkan dengan melakukan observasi ini, peneliti nantinya akan membandingkan kesesuaian pernyataan yang disampaikan oleh para informan dengan perilakunya seharihari. Apabila terdapat kesesuaian maka hasil wawancara itu benar adanya, namun jika terdapat perbedaan, maka peneliti harus berusaha lebih keras lagi untuk melakukan pendekatan dengan para informan karena bisa jadi, kurangnya ketelatenan dalam sebuah hubungan menyebabkan informan menjadi kurang terbuka dengan peneliti.

Pada penelitian ini teknik analisis data yang digunakan adalah analisis data model interaktif miles dan huberman (Sugiyono, 2008). Berikut gambaran proses analisis data Menurut Miles dan Huberman dapat dilihat pada gambar berikut.

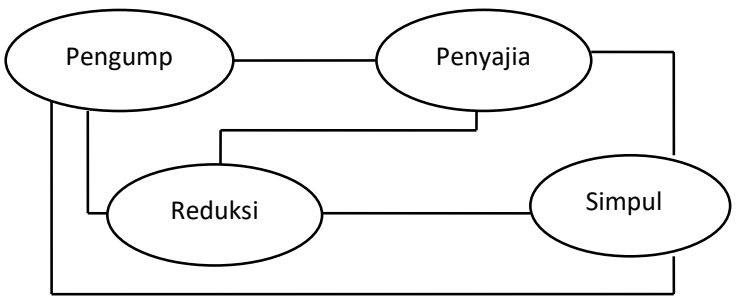

Gambar 1. Proses Analisis Data Sumber: (Bungin, 2010)

Serta teknik validitas data menggunakan triangulasi. Teknik triangulasi ialah teknik pemeriksaan keabsahan data yang memanfaatkan sesuatu yang lain diluar data itu untuk keperluan pengecekan atau sebagai pembanding terhadap data itu. Adapun teknik triangulasi yang peneliti lakukan adalah triangulasi sumber.

\section{B. HASIL DAN PEMBAHASAN}

Menurut informasi yang dikeluarkan oleh Asosiasi Penyelenggaraan Jasa Internet (APJII) bahwasanya pulau Jawa menempati posisi pertama sebagai wilayah dengan penggunaan internet tertinggi di Indonesia, dan Jawa Barat menjadi salah satu provinsi yang menempati urutan teratas dalam hal penggunaan internet. Selain itu alasan men- 
gapa dipilih mahasiswa dikarenakan sebagaimana dijelaskan pada pendahuluan bahwasanya mahasiswa merupakan objek yang paling banyak menggunakan internet.

Pada penelitian ini, Peneliti akan mewawancarai 5 orang informan untuk penelitian ini. Berikut adalah data informan:

Tabel 1 Data Informan Sumber: Hasil Penelitian, 2018

\begin{tabular}{|c|c|c|c|c|c|}
\hline No & Nama & $\begin{array}{c}\text { Umur } \\
\text { (Tahun) }\end{array}$ & $\begin{array}{l}\text { Kuanti } \\
\text { tas } \\
\text { Jumlah }\end{array}$ & $\begin{array}{c}\text { Kuantitas } \\
\text { Pengguna } \\
\text { an Hp }\end{array}$ & $\begin{array}{cc}\text { s } & \text { Data } \\
\text { a } & \text { Paket }\end{array}$ \\
\hline 1 & $\begin{array}{l}\text { Nn. } \\
\text { FM }\end{array}$ & 25 & 4 & $5 \mathrm{Jam}$ & $\begin{array}{c}10 \\
\text { GB+Wifi }\end{array}$ \\
\hline 2 & $\begin{array}{l}\text { Nn. } \\
\text { RAW }\end{array}$ & 25 & 5 & $10 \mathrm{Jam}$ & $16 \mathrm{~GB}$ \\
\hline 3 & Nn. TK & 27 & 5 & $15 \mathrm{Jam}$ & $\begin{array}{c}3 \\
\text { GB+Wifi }\end{array}$ \\
\hline 4 & $\begin{array}{c}\text { Nn. } \\
\text { WIH } \\
\text { Nn. RY }\end{array}$ & 24 & 3 & 4 Jam & $\begin{array}{c}500 \\
\mathrm{MB}+\mathrm{Wif} \\
\mathrm{i} \\
12 \mathrm{~GB}\end{array}$ \\
\hline
\end{tabular}

Diantara banyak media komunikasi yang digunakan salah satunya adalah mobile phone atau bisa juga disebut handphone (hp). Mobile phone adalah telepon dengan antena tanpa kabel yang dapat dibawa kemana-mana. saat ini banyak jenis mobile phone diciptakan guna memudahkan aktivitas mahasiswa, selain bisa menggunakan mobile phone untuk menelepon, mengirim sms (short message service) namun saat ini bisa juga digunakan untuk menyelesaikan tugas perkuliahan, menjadi sumber informasi, hiburan dan sebagainya. diantara kelima informan yang peneliti amati, mereka memiliki motif yang berbeda-beda terkait penggunaan mobile phone.

Adapun motif para informan dalam No. SK Akreditasi Ristekdikti : 34/E/KPT/2018 menggunakan mobile phone, sebagai berikut . Untuk mencari informasi, sebagai sarana untuk mengetahui kehidupan orang lain, dan sebagai kebutuhan terkait pekerjaan. WIH mengatakan bahwasanya ia menggunakan mobile phone untuk mencari informasi dan sarana untuk kepoin orang, sebagaimana kutipan di bawah ini.

"Kalau motif menggunakan hp selain mencari informasi tetapi juga main instagram buat kepoin orang, paling kayak gitu aja" (Berdasarkan wawancara dengan WIH tanggal 10 Maret 2018).

Selain itu hal senada juga disampaikan oleh TK dan RY yang memiliki pendapat yang sama dengan WIH, seperti kutipan di bawah ini.

"Alasan pakai Hp ya biar tetap terhubung dengan teman-teman yang lain, terus kalau mau cari informasi juga lebih gampang" (Berdasarkan wawancara dengan TK tanggal 10 Maret 2018).

Pernyataan diatas juga disetujui oleh RY, sebagaimana hasil wawancara berikut :

"Pakai hp karena kebutuhan, terus buat sumber informasi juga" (Berdasarkan wawancara dengan RY tanggal 13 Maret 2018).

Pendapat lainnya juga disampaikan oleh RAW dan FM, yang mana alasan menggunakan mobile phone karena berhubungan dengan pekerjaan mereka di media. Berikut kutipan wawancaranya.

"Karena aku kerja di media, jadi mau gak mau harus megang hp terus, karena kadang mengecek pesan dari teman sesama kerjaan atau mau ngirim beri-

DOI:https://doi.org/10.17509/e.v18i2.17134 
ta" (Berdasarkan wawancara dengan RAW tanggal 10 Maret 2018).

Hal serupa juga diungkapkan oleh FM yang berprofesi sebagai jurnalis di sebuah media start up, sebagaimana kutipan berikut "Semua kerjaan itu ada di HP, jadi kalau pergi-pergi juga tetap harus aktif di hp karena setiap hari harus update berita" (Berdasarkan wawancara dengan FM tanggal 20 Maret 2018).

Seperti yang sudah dijelaskan pada hasil wawancara diatas, dimana rata-rata informan memilih untuk menggunakan mobile phone dikarenakan kebutuhan akan informasi. Hal ini juga diperkuat dari pernyataan yang disampaikan oleh Yusup dan Saepudin bahwa jika dihitung berapa banyaknya informasi di dunia ini, maka tidak seorangpun yang bisa menghitung berapa banyaknya informasi yang pernah dilahirkan karena jumlah informasi yang terus berkembang tak terbatas seiring dengan semakin banyaknya jumlah manusia yang dilahirkan dan semakin banyaknya gagasan manusia yang melahirkan informasi (Ope Destrian, 2018).

Berikutnya adalah budaya, adapun perubahan mengenai budaya ini akan dibahas lebih lanjut dengan kaitannya pada ritual diri dari mahasiswa dengan kecenderungan nomofobia. Adapun ritual diri yang dirasakan oleh para informan dengan kecenderungan nomofobia seperti yang disampaikan berdasarkan wawancara berikut :

"Bangun tidur yang pasti biasanya kalau liat HP ya paling liat jam, oh jam segitu.. Hp letaknya di samping tapi agak jauh, kadang Hp nya letaknya di luar atau di dalam tas gak dikeluarin.

No. SK Akreditasi Ristekdikti : 34/E/KPT/2018
Kalau sebelum tidur ada ngecek grup WA ada info apa nggak, kalau di kampus kadang nyala itu juga karena HP nya memang online terus padahal lagi gak online." (berdasarkan wawancara dengan WIH tanggal 10 Maret 2018).

Seperti hasil wawancara diatas dengan WIH, kegiatan nya dalam menggunakan mobile phone seperti bangun tidur melihat mobile nya terlebih dahulu lalu ketika hendak tidur juga melakukan hal yang sama. ini menjadi ritual bagi dirinya sendiri dalam menggunakan mobile phone.

Selain itu pernyataan lainnya juga disampaikan oleh TK terkait ritual diri yang dilakukannya, sebagaimana kutipan wawancara berikut :

"Pas pertama bangun pasti ngeliat HP gitu ngeliat jam karena jadwal kuliah pagi gitu ya kan, terus cek-cek message -message yang lain, whatsapp, instagram atau pesan gitu siapa tau ada pesan dari teman-teman kuliah gitu, udah gitu taruh HP dulu karena mau rutintas mandi, terus ngecek lagi udah jam berapa, dandan, ganti baju, gitu gitu, trus mau berangkat gitu main HP dulu liat instagram, liat-liat foto yang lucu atau upload foto sendiri. Udah sih gitu aja... sampai akhirnya tidur lagi..lebih kurang 15 menit nge cek HP lagi" (Berdasarkan hasil wawancara dengan TK tanggal 10 Maret 2018).

RY pun memiliki ritual diri yang relatif sama dengan yang disampaikan WIH dan TK, ia mengatakan bahwa ketika menggunakan mobile phone ia bahkan tidak bisa menghitung berapa kali ia menggunakannya dalam sehari karena terlalu seringnya. Hal ini sesuai dengan kutipan wawancara berikut :

"Kalau dari bangun tidur sih liat HP lebih kayak baca informasi tentang ada kegiatan apa di kelas kayak pengumpulan

DOI:https://doi.org/10.17509/e.v18i2.17134 
tugas atau informasi-informasi yang berkaitan tentang bertita-berita terbaru, macammacam sih.. kadang suka ngecek-ngecek Hp sejam sekali, kalau tidur HP letaknya di meja tapi gak jauh masih di dalam kamar. Kalau makan dan solat benar-benar gak megang HP. Sering dengerin musik juga, kalau pas suntuk ngerjain tugas, terus sebelum tidur ngecek HP kayak negcek informasi atau buka media sosial" (berdasarkan wawancara dengan RY tanggal 13 Maret 2018).

Selanjutnya ritual diri dalam menggunakan mobile phone yang dilakukan oleh RAW dijelaskan dalam wawancara berikut:

"Jadi aku sebelum tidur itu matiin paket data, habis matiin paket data kan tidur tu, dah tidur pas bangun aku aktifin paket datanya, terus cek siapa aja yang nge chat, udah dibalesin udah deh terus nanti berangkat kuliah atau ada kegiatan kemana gitu. Terus paling ngecek HP lagi pas ada chat aja, biasanya kalau udah agak lama gak ada yang nge-chat tetap aja dibuka takut ada yang nge-chat siapa gitu. Terkadang juga ngeliat HP untuk liat jam karena gak punya jam tangan juga kan. Jadi gitu" (Berdasarkan wawancara dengan RAW tanggal 10 Maret 2018).

Penjelasan berikutnya juga diperkuat dengan pernyataan yang disampaikan oleh FM, yang mengatakan bahwasanya ia pun merasakan dan melakukan hal serupa seperti yang dilakukan oleh RAW sebagai berikut :

"Kalau bangun tidur buka HP ya karena matikan alarm, terus sama ngeliat udah azan subuh apa belum. Itu sih, terus paling buka sosmed itu jam 6 karena saya harus ngecek berita pagi anak-anak yang di Jakarta itu. Terus seterusnya sampai sore kalau lagi ada luangnya, kayak sekarang ni selesai kuliah dibuka, karena mau ngecek kan ada wa grup atau info

No. SK Akreditasi Ristekdikti : 34/E/KPT/2018 dari kerjaan. Terus ya udah dari pagi sampai sore kayak gitu rutinitasnya. Terus kalau malam itu habis isya, biasanya saya udah tidur. Jadi paling sebelum tidur juga nonton youtube. Hp letaknya di samping, terus kadang kalau ingat di taruh di atas meja tapi kalau gak ingat udah ditidurin aja Hp nya. Pernah dulu bawa Hp ke kamar mandi, nah itu yang hilang ketinggalan itu di Wc. Tapi kalau sekarang udah nggak, paling kalau lagi di jalan tapi kan itu di tas. Panik kalau Hp nya tiba-tiba gak ada dekat kita, pernah tu kayak kejadian yang di kantin itu.. terus kayak ini sih seringnya pas mau pergi, jadi mastiin dulu udah bawa Hp apa belum karena kalau aku tuh udah keluar rumah atau kosan sekali baru pulang pas malam atau sore jadi harus dipastiin" (Berdasarkan hasil wawancara dengan FM pada tanggal 20 Maret 2018).

Tentu ini bisa mendatangkan kekhawatiran dimasa yang akan datang, dimana ketika mobile phone mampu mengubah seseorang bahkan budaya pada suatu bangsa. Bukan tidak mungkin, Indonesia akan menjadi Negara dengan budaya individualisme yang tinggi. Dimana setiap orang akan merasa tidak perlu berhubungan lagi secara langsung atau tatap muka namun cukup melalui mobile phone saja. Karena sebaik-baik dari komunikasi adalah komunikasi secara tatap muka, sebagaimana yang disampaikan oleh Joseph A. Devito dalam bukunya interpersonal communication (Devito, 2007).

Selanjunya akan dibahas mengenai kaitan nomofobia dengan teknologi. seperti yang dijelaskan pada tinjauan pustaka bahwasanya nomofobia merupakan bentuk kecemasan yang luar biasa oleh seseorang diakibatkan karena penggunaan mobile phone.

Jika kita kaitkan maka fenomena yang DOI:https://doi.org/10.17509/e.v18i2.17134 
terjadi saat ini dimana manusia tidak bisa lepas dari yang namanya teknologi. karena sejatinya teknologi diciptakan untuk memudahkan segala kegiatan manusia. berikut akan dijelaskan lebih lanjut mengenai pemaknaan mobile phone oleh mahasiswa dengan kecenderungan nomofobia.

Adapun pemaknaan terhadap mobile phone sebagai berikut. Sebagai sumber informasi, sebagai alat yang menghubungkan dengan orang lain, dan sebagai sumber penghasilan.

Sementara itu informan yang memaknai mobile phone sebagai sumber informasi yakni dua orang, WIH dan RY. Berikut kutipan wawancara yang dilakukan dengan WIH.

"Makna HP sendiri itu rasanya karena memang info itu liatnya dari HP jadi kalau ketinggalan satu info tu rasanya wah kayak mana gitu.. jadi harus makai HP terus. HP nya pernah hilang, jadi waktu itu tetap ada pakai Hp mama" (Berdasarkan wawancara dengan WIH tanggal 10 Maret 2018).

Selanjutnya pernyataan yang disampaikan oleh RY mengenai pemaknaannya terhadap mobile phone sebagaimana kutipan di bawah ini.

"Lebih ke sarana yang menghubungkan untuk memperoleh informasi, atau mencari informasi-informasi yang dibutuhkan selama menjadi mahasiswa, karena kalau ada pemberitahuan pasti di share nya di HP jadi biasanya kalau bangun tidur juga pasti yang diliat HP karena pengen tau informasi terbaru apa yang berkaitan dengan perkuliahan" (Berdasarkan wawancara dengan RY tanggal 13 Maret 2018).

Selain itu pemaknaan lainnya terkait mobile phone adalah sebagai alat yang menghubungkan dengan orang lain, berikut kutipan wawancara yang dilakukan dengan No. SK Akreditasi Ristekdikti : 34/E/KPT/2018
TK.

"HP itu ya suatu alat yang bisa aku gunakan untuk sumber menghubungkan aku dengan orang lain. Pernah panik, nangis waktu HP itu kesiram air, aku pernah.. kayak ada ngerasa ilang terus sedih, kayak aku kehilangan seseorang, kayak ngerasa ada yang hilang gitu aja. Sehari bisa gak pakai HP tapi gak bisa lebih dari 1 hari karena bakalan ngerasa ada yang hilang" (Berdasarkan wawancara dengan TK tanggal 10 Maret 2018).

Di antara kedua pemaknaan di atas, ada pula yang memaknai mobile phone sebagai sumber penghasilan. Berikut kutipan wawancara yang dilakukan dengan RAW.

"Kenapa aku bisa bergantung dengan mobile phone karena semua kerjaan aku di media" (Berdasarkan wawancara dengan RAW tanggal 10 Maret 2018).

Selanjutnya pernyataan yang sama juga disampaikan oleh FM mengenai pemaknaannya terhadap mobile phone, adapun kutipan wawancaranya sebagai berikut.

"Karena kerjaan saya based on online ya kayak dari grup whatsapp kantor ya, karena harus me-manage grup jurnalis di Jakarta kalau yang sekarang ya karena domisili di jatinangor. Terus yang kedua, kalau misalnya pun lagi di jalan itu tetap harus online karena editing berita itu lewat online, terus kayak media sosial gitu kayak facebook sama twitter, sebenarnya saya pribadi untuk akun sosmed dua ini ya twitter dan facebook udah gak pakai, saya punya akun tapi saya udah gak aktif lah gitu, cuman karena saya admin jadi saya mau gak mau harus pakai, jadi harus aktif gitu"( Berdasarkan wawancara dengan FM tanggal 20 Maret 2018).

\section{SIMPULAN}

Simpulan dari penelitian adalah bahwa terdapat kaitan yang erat antara Nomofobia dengan perspektif media, budaya dan teknologi. Adapun nomofobia dalam per-

DOI:https://doi.org/10.17509/e.v18i2.17134 
spektif media khususnya media nya yakni mobile phone dapat dilihat dari motifnya dalam menggunakan mobile phone itu sendiri. Diantara motif mereka menggunakan mobile phone yakni Untuk mencari informasi, sebagai sarana untuk mengetahui kehidupan orang lain, dan sebagai kebutuhan terkait pekerjaan. Sementara itu, nomofobia dalam perspektif budaya dapat dilihat dari bagaimana mobile phone mengubah budaya dari para mahasiswa dengan kecenderungan nomofobia tersebut. Budaya yang berubah ini dapat dilihat dari ritual diri yang dilakukannya, Adapun ritual diri dari mahasiswa dengan kecenderungan nomofobia dimana mereka sehari-harinya bergantung dengan hadirnya mobile phone, baik itu dimulai dari bangun tidur, sebelum berangkat ke kampus atau ketika hendak mandi, selesai mandi, bahkan ada beberapa informan yang tetap membawa mobile phone nya ke kamar mandi, di kampus hingga akhirnya ketika hendak tidur juga tidak ketinggalan untuk mengecek mobile phone nya. Sementara itu dari segi perspektif nomofobia terhadap teknologi dapat dilihat dari pemaknaan para mahasiswa mengenai mobile phone itu sendiri, diantara pemaknaan para informan mengenai mobile phone yakni, ada yang memaknainya sebagai sumber informasi, ada juga yang mengatakan sebagai alat yang menghubungkan dengan orang lain, dan ada juga yang memaknainya sebagai sumber penghasilan.

Berikut gambaran dari kategorisasi hasil penelitian terkait nomofobia dalam perspek-

No. SK Akreditasi Ristekdikti : 34/E/KPT/2018 tif media,budaya dan teknologi :

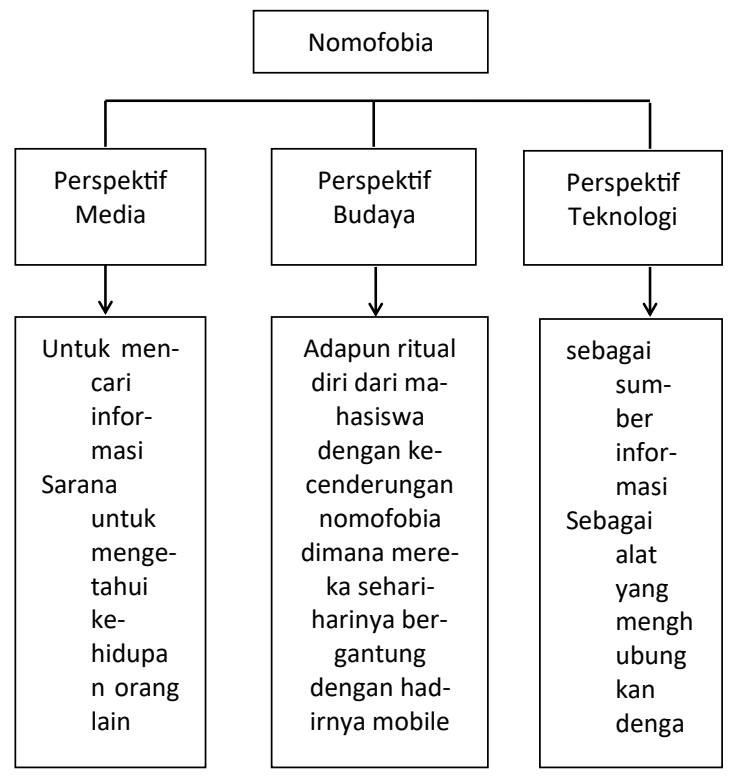

Gambar 2. Kategorisasi Hasil

Penelitian

Sumber : Hasil Penelitian 2018

Adapun saran yang penulis berikan disini yakni agar kedepannya penelitian mengenai nomofobia khususnya berkaitan dengan kajian komunikasi agar lebih ditingkatkan lagi, karena kebanyakan penelitianpenelitian sebelumnya berasal dari kedokteran, komputer, psikologi dan ilmu eksak lainnya sehingga penelitian nomofobia dalam bidang komunikasi masih jarang ditemui, padahal jika dikaji lebih dalam banyak hal yang masih dapat ditelaah lebih dalam seperti kaitan nomofobia dengan komunikasi interpersonal dan sebagainya.

\section{DAFTAR PUSTAKA}

Alter, A. (2017). Irresistible. London: The Boadley Head. 
APJII. (2017). Penetrasi dan Perilaku Pengguna Internet Indonesia. Indonesia: APJII.

Ardianto, E. (2011). Metodologi Penelitian Untuk Public Relations Kuantitatif dan Kualitatif. Bandung: Simbiosa Rekatama Media.

BIVIN.J.B. (2013). NOMOFOBIA - DO WE REALLY NEED TO WORRY ABOUT? A cross sectional study on Nomofobia severity among male Under Graduate students of Health sciences. Vol -1, ISSUE -1, 1-5.

Bungin, B. (2010). Metodologi Penelitian Kualitatif : Aktualisasi Metodologis Ke Arah Ragam Varian Kontemporer. Jakarta: Raja Grafindo Persada.

Davie, N. (2017). NOMOFOBIA: IS SMARTPHONE ADDICTION A GENUINE RISK FOR MOBILE LEARNING? 13th International Conference Mobile Learning (pp. 100104). Germany : researchgate.

Devito, J. A. (2007). Komunikasi Antarmanusia 5th.ed. Terjemahan; Agus Maulana (et.al.). Jakarta: Karisma Publishing.

Dongre, A. S. ( 2017 ). Nomofobia: A Study to Evaluate Mobile Phone Dependence and Impact of Cell Phone on Health. National Journal of Community Medicine Volume 8 Issue 11, 688-693.

Hardianti, F. (2016). KOMUNIKASI INTERPERSONAL PENDERITA NOMOFOBIA DALAM MENJALIN HUBUNGAN PERSAHABATAN

No. SK Akreditasi Ristekdikti : 34/E/KPT/2018
(Studi Pada Mahasiswa Ilmu Komunikasi di Universitas Riau) . JOM FISIP Vol. 3 No. 2 , 1-14.

Kar, S. ( 2017 ). PREVALENCE OF NOMOFOBIA AMONG MEDICAL STUDENTS IN A PRIVATE COLLEGE OF BHUBANESWAR, ODISHA . J.Bio.Innov6 .

kbbi. (2018). KBBI. Retrieved Mei 28, 2018, from kbbi.web.id: http://kbbi.web.id/ media

Kim, H. (2013). Exercise rehabilitation for smartphone addiction. Journal of Exercise Rehabilitation, Vol. 9, No. 6, 500-505.

King, A. L. (2014). "Nomofobia": Impact of Cell Phone Use Interfering with Symptoms and Emotions of Individuals with Panic Disorder Compared with a Control Group . Clinical Practice \& Epidemiology in Mental Health, 10, 28-35.

Kuswarno, E. (2009). Fenomenologi. Bandung: Widya Padjadjaran.

Mahenda, A. R. (2013). Gangguan Kesehatan Akibat Nomofobia Pada Mahasiswa Universitas Airlangga Surabaya. Surabaya: Universitas Airlangga.

Ope Destrian, d. (2018). Perilaku Pencarian Informasi Pertanian melalui Media Online pada Kelompok Petani Jahe. Jurnal Kajian Komunikasi, Volume 6, No. 1, 121-132.

Ruslan, R. (2010). Manajemen Public Relations dan Media Komunikasi. Jakarta:

DOI:https://doi.org/10.17509/e.v18i2.17134 
Rajawali Pers.

Saefudin, A. (2008). Perkembangan Teknologi Komunikasi : Perspektif Komunikasi Peradaban. MEDIATOR Vol.9 No. 2, 383-392.

Sjafirah, N. A. ( 2016 ). PENGGUNAAN MEDIA KOMUNIKASI DALAM EKSISTENSI BUDAYA LOKAL BAGI KOMUNITAS TANAH AKSARA STUDI DESKRIPTIF KUALITATIF TENTANG PENGGUNAAN MEDIA KOMUNIKASI DALAM EKSISTENSI BUDAYA LOKAL BAGI KOMUNITAS TANAH AKSARA DI BANDUNG . Jurnal Ilmu Politik dan Komunikasi Volume VI No. 2 , 39-50.

Sugiyono. (2008). Metode Penelitian Kuantitatif, Kualitatif, dan R\&D. Bandung: Alfabeta.

Yildirim, C. (2015). Exploring the dimensions of nomofobia: Development and validation of a self-reported questionnaire. Computers in Human Behavior, volume 49, 130-137. 